\title{
OPERA TRINITATIS AD EXTRA AND COLLECTIVE AGENCY
}

\author{
ADONIS VIDU \\ Gordon-Conwell Theological Seminary
}

\begin{abstract}
This paper assesses the viability of the model of 'collective action' for the understanding of the doctrine of the inseparability of trinitarian operations, broadly conceived within a Social-Trinitarian framework. I argue that a 'loose' understanding of this inseparability as 'unity of intention' is insufficiently monotheistic and that it can be 'tightened' by an understanding of the ontology of triune operations analogically modelled after collective actions of a 'constitutive' kind. I also show that attention to the 'description relativity of action ascriptions' can potentially move us beyond the impasse of the doctrine of appropriation. Finally, I respond to potential objections.
\end{abstract}

\section{INTRODUCTION}

This paper addresses the intelligibility of what I have called the 'twin principles' of classical Western Trinitarian theology: the doctrine of inseparable operations and the corollary doctrine of appropriation. Latin Trinitarianism (LT) understands the former doctrine to teach that economic divine agency belongs to the Trinity as a whole, with particular actions such as creation, redemption, incarnation, etc., being appropriated to one of the divine persons. Social Trinitarianism (ST), on the other hand, wants to preserve the distinctive agency of each of the persons, in some cases reading the former doctrine in terms of a unity of intention. Talk of this unity of intention is then expected to preserve the motivation and purpose of the opera ad extra principle without inviting its problematic implications such as the doctrine of appropriation. 
One of my purposes is to test this 'looser' conception of the unity of external operations. I will be assuming, for the sake of argument, the overall framework of ST and will ask whether this account of unity sufficiently preserves the motivations for the ancient embrace of the concept of inseparable operations. My conclusion will be that, without further supplementation, such an account of unity is insufficiently preserving of those intuitions. This leads me to suggest that we might better describe the unity of external action in terms of collective agency, appropriately described. Such an analogy can help ST preserve both the unity of economic action, as well as its stress on distinctive agencies of the persons.

I start the conversation with a summary of recent discontent about the two doctrines and a presentation of an alternative conception of unity centred around intentions. I then explore the grammar of the doctrine in the Cappadocian fathers. Next, I draw on two items of the philosophy of action: the description relativity of action ascriptions, and the notion of collective actions. The last two sections test the Trinitarian viability of this model and address some objections.

\section{RECENT CRITIQUES OF THE 'TWIN PRINCIPLES’}

During the last few decades the 'twin principles' of inseparable operations and appropriation have been subjected to a concerted critique. Ted Peters summarizes the discontent well: 'Here is the problem: should one want to press to the limit the implications of Augustine's maxim that the operations of God in the world are undivided (opera trinitatis ad extra sunt indivisa), then we would have to say that the Nicene creed borders on the unorthodox - it divides the work. [...] Each person of the Trinity, in turn, has a different function. The work of the one God seems divided.' (Peters 1983: 33) To put it differently, the differentiation that is manifest in the economy seems to divide the operations. Peters also mentions the alleged implications of the principles, some of which are notorious, such as Aquinas' suggestion that any one of the divine persons might have become incarnate (Aquinas 1981: III.3.1). This seems to further rob revelation of any epistemic purchase. The fact that it is the Son who has become incarnate, and not the Father or the Spirit, tells us nothing, it would seem, about the immanent identity and personhood of the Son.

Catherine Mowry LaCugna also leans heavily against Augustine in her pivotal work, God For Us: The Trinity and Christian Life. She claims 
that Augustine's principle 'follows logically from the starting point in the divine unity instead of the economy of salvation' (LaCugna 1993: 98). LaCugna continues: 'once it is assumed that the Trinity is present in every instance where Scripture refers to God, and once the axiom of opera ad extra is in place, no longer, it seems, is there any need for the plurality of persons in the economy. At least it is no longer possible to single out any person in relation to a particular activity. The Triune God's relationship to us is unitary'. (LaCugna 1993: 99) This does raise an important point in relation to ascription of actions. We recognize a threefoldness in God precisely because of a differentiation in divine action in the world. However, if this differentiation is ultimately denied, it would seem we no longer have a basis for making such distinctions in the very being of God. The importance of this point can hardly be overestimated. I will return to it very shortly.

LaCugna's work comes on the heels of Rahner's critique of the Western separation between the immanent and the economic Trinity. He admits that there are appropriated relations between the Trinity and the world. Such actions are appropriated 'only where the supreme efficient cause is concerned' (Rahner 1970: 77). Rahner operates here a distinction between supreme efficient causality and what he calls a 'quasi-formal causality' (Rahner 1970: 36). There are ways in which God acts in the world as a single agent, as it were. The distinctions we may make between the outcomes of those actions are not to be projected back into the divine agency. This is very much an Augustinian (as well as a Cappadocian) view. However, Rahner insists that not all divine actions fit into that pattern. Were that so, the incarnation could not be ascribed to the person of the Son, but it would equally have to be predicated of the Father and the Spirit.

An un-nuanced understanding of the opera ad extra principle and its implied doctrine of appropriation would indeed seem to warrant such a reading. The agency in this case would seem to be ascribed to the Trinity as a whole, simpliciter. And in this case, appropriation would be a mere linguistic device, with no real epistemic purchase. It would simply indicate that the Scriptures mandate - as a matter of arbitrary convention - that the incarnation is referred to the Son.

Rahner counters that the incarnation should be regarded as a 'dogmatically certain instance for an economic relation proper to each person, of the divine persons in the world' (Rahner 1970: 27). In other words, there is no qualification and correction to be made to our 
common-sense observation that this action (incarnation) is ascribed to the second person of the Trinity. The persons have distinct economies. Taking revelation seriously should force us into this conclusion, Rahner insists.

To the question whether this threatens the unity of the divine essence in any way, Rahner does not apply himself with much care. He does state that such a construal is still compatible with God still having a single (one) relation to the world, "but precisely a relationship which refers him as threefold, each person in his own way, to the world' (Rahner 1970:28).

An immediate question, though, would be: if the incarnation is a dogmatically certain instance of God's economy, on what economic basis can we still conclude that the actions of Father, Son, and Holy Spirit are not the actions of three gods? How is the unity of the divine substance to be secured and prevented from it being divided among the persons?

Christoph Schwöbel's seminal work, God: Action and Revelation proposes precisely such an account that preserved the general lines of Rahner's insistence on the incarnation as a dogmatically certain instance of personal economy. His solution is to speak of the unity of these differentiated actions as a unity of intention. This, he thinks, is sufficient to preserve the grammar and aim of the ancient principle: 'The unitary intention which is contained in the internal relatedness of the three types of action is expressed in the insight of traditional trinitarian theology: opera trinitatis ad extra sunt indivisa.' (Schwöbel 1992: 43)

The unity of God's external operations is not something that flows from a prior metaphysical construal of God's essence, but something that needs to be derived from bottom up, starting and assuming the differentiation of divine actions: 'If we can construe the internal relatedness of the action of God, Father, Son, and Spirit in such a way, we can express the unity of divine agency in the differentiation of God's actions in the divine economy. This is the essential element of truth in the in other ways very problematical thesis of Western trinitarian thought opera trinitatis ad extra sunt indivisa.' (Schwöbel 1992: 56-7)

Like Rahner, Schwöbel senses that the difficulty derives from the creeping influence of the metaphysical attributes of God, defined primarily in terms of substance. Such a conception of the attributes of God needs to be reconfigured in terms of action. The only way, he argues, that we can even individuate divine action is if we reformulate the metaphysical attributes of God (omnipotence, omnipresence, eternity, etc.) within the framework of intentional agency. Metaphysical descriptions of divine 
attributes exclude, among other things, temporality. But '[p]recisely what is excluded in this way, however, constitutes the necessary conditions for individuating actions and for identifying agents' (Schwöbel 1992: 52). This is also a very important point, in fact related closely to LaCugna's comments about action ascriptions. Unless we are prepared to recognize the reality of temporal and personal differentiation, we shall have no means of individuating divine actions, and more importantly of identifying agents.

Schwöbel does not explain exactly why this is a problem. Nor does he put forward a very substantive defence of the claim that an intentional unity sufficiently expresses the grammar of the problematic principle of the opera ad extra. Such a defence is absolutely essential, for, as I will show, there are models of cooperative action which are insufficiently expressive of the unity (and simplicity) of the divine nature. To see this I now turn to the Cappadocian grammar of inseparable operations.

\section{THE CAPPADOCIANS AND INSEPARABLE OPERATIONS}

That the Cappadocian fathers affirm the principle of unity of external operations is noncontroversial. Basil the Great affirms it in relation to understanding the work of the Spirit: 'The Holy Spirit is inseparable and wholly incapable of being parted from the Father and the Son [...] in every operation.' (Basil the Great 1999: ch. XVI, sect. 37; see also ch. VI, sect. 15) One of the functions of this principle in Basil's work on the Spirit is to demonstrate the divinity of the Spirit by showing that his actions are at the same time the actions of the Father and the Son. As several writers have shown recently (cf. Holmes 2001; Holmes 2012: 107; Barnes 2001: ch. 7), the Cappadocians use the principle of the unity of external operations as a means of demonstrating a common nature.

The unity of operations is not meant simply to say that Father, Son, and Spirit all do the same action types, independently of one another. Such an argument is indeed present in, say, Nyssen. In Against Eunomius, he argues that since the Father, Son, and Spirit do the same kinds of actions, they share a unity of power. But unity of power implies unity of nature, hence the Son and the Spirit share in the divine nature.

While this argument is sufficient to establish a unity of divine nature, it still left open the possibility of tritheism. Thus, as Barnes (2001: 299) shows, Gregory of Nyssa shifts, in On the Holy Trinity and On 'Not Three Gods' to an argument that proceeds from unity of activity to 
unity of nature. Unlike the case of human actions, which several people might similarly do without erasing their own proper distinctness and individuality, trinitarian monotheism requires the claim that every divine action is equally participated in by all trinitarian persons (Barnes 2001: 303).

The action of cleansing from sin, for example, is attributed to both Spirit (Rom 8:2,13) and Christ (1 John 1:9), and God the Father (Isa $1: 16-18)$. Clearly this is not the case of the Son cleansing some, the Spirit others, but both being involved in the same action. As Barnes comments: 'Thus Christ and the Spirit have the same ergon, product. But if the two have the same activity, then they must have the same nature. Just as the appearance of the properties illuminating and burning must indicate the same nature, fire, so too much common activity indicate the same nature of the Son and Spirit.' (Barnes 2001: 303)

For Gregory's argument to work, then, it is not sufficient that the two work in common, with the intention of achieving a common end. Rather, they must each be involved in each other's activities. 'Thus', writes Nyssen, 'since among men the action of each in the same pursuits is discriminated, they are properly called many since each of them is separated from the others within his own environment, according to the special character of his operation. But in the case of the Divine nature we do not similarly learn that the Father does anything by Himself in which the Son does not work conjointly, or again that the Son has any special operation apart from the Holy Spirit; but every operation which extends from God to creation, and is named according to our variable conceptions of it, has its origin from the Father, and proceeds through the Son, and is perfected in the Holy Spirit. [...] For this reason the name derived from the operation is not divided with regard to the number of those who fulfil it, because the action of each concerning anything is not separate and peculiar, but whatever comes to pass, in reference either to the acts of His providence for us, or to the government or constitution of the universe, comes to pass by the action of the Three, yet what does come to pass is not three things.' (Gregory of Nyssa 2004: 334)

The above excerpt is extremely careful in the distinctions it is making. They bear directly on my thesis. Nyssen insists that, unlike the operations of man, which although similar and related, are nevertheless ascribed to different agents (identified by plural nouns), the actions of God bear a common agency, of the three persons together. Gregory feels compelled to say this because he is interested in preventing tritheism. 
A second distinction made by Gregory is that between our perception of distinction and multiplicity, and the ultimate and transcendent unity of divine action. What appears to us are 'three things', whereas the action of God is really one and indivisible. Human actions are indeed 'separate and peculiar', whereas Triune action is indivisible and unified.

The lack of distinction between what the persons bring about is an essential part of the grammar of the Cappadocian concept. It serves Nyssen's ultimate purpose, of safeguarding the unity and simplicity of the divine essence, as opposed to the division of human nature. And it is precisely 'the unity existing in the action [which] prevents plural enumeration' (Gregory of Nyssa 2004: 335). Temporal distinction is also excluded: 'every good thing and every good name, depending on the power and purpose which is without beginning, is brought to perfection in the power of the Spirit through the Only-begotten God, without mark of time or distinction (there is no delay, existent or conceived, in the motion of the divine will from the Father, through the Son, to the Spirit).' (Gregory of Nyssa 2004: 335)

Let me try to spell out why I think these distinctions are important for the Cappadocians. Take cases of human collective action, for example, the case of a team of builders constructing a house. While all of these builders share a common purpose and common intentions, they each do different actions, some in complete isolation from each other. The person driving the nail, for example, does it in isolation from the one painting the interior walls, and so on. These actions are distinct. Moreover, there is a temporal duration between these actions such that one agent must await the successful completion of other actions before he commences his.

While we can certainly infer a common nature from these activities (these are all men), we shall have to call them by different names. Their activities are sufficiently distinct and different, so that they 'are properly called many', their nature being divisible.

Thus, the Cappadocian construal of the unity of external operations is sufficiently precise to caution against construals of such a unity merely in terms of a common intention. The agencies of Father, Son, and Spirit must be mutually involved in each other, such that the common action of the Trinity cannot be broken into simpler constituent actions. Basil is quite explicit on this latter point: 'the operation of the Father who worketh all in all is not imperfect, neither is the creating work of the Son 
incomplete if not perfected by the Spirit.' (Gregory of Nyssa 2004: ch. xvi, sect. 38)

I have chosen to focus on the Cappadocian account of the inseparability of trinitarian operations, since the Cappadocian account of the Trinity is often invoked to support so-called 'social Trinitarianism'. My argument is that accounts of this unity in terms of a shared intention are insufficient to preserve the requisite monotheism of trinitarian doctrine. Such accounts of cooperative action have been consistently rejected as anthropomorphic by the Cappadocians. Moreover, the assumption of the Cappadocian approach is that the doctrine of the inseparable operations is not an optional extra, but that it is an implication as well as a presupposition of monotheism. The question is now whether it is possible to account for this inseparability from within a broadly Social Trinitarian framework. However, such a model should also be able to preserve ST's important emphasis on the epistemic significance of revelation. To use the all important example, can the incarnation be predicated specifically to the Son without undermining the inseparability of external operations?

The next sections test the model of collective action (appropriately understood) as an affirmative answer to these questions.

\section{DESCRIPTION RELATIVITY OF ACTION ASCRIPTIONS}

Theologians are engaged in a debate over the ontology of divine action. They are asking the question: how many actions are being performed ad extra and who (how many?) are the subjects of these actions. Some are insisting that the agent of all opera ad extra is the Trinity, taken as a whole. Others, conversely, claim that the divine economy is composed of distinct actions, performed by distinct agents.

In their disagreement over the ascription of responsibility (or agency), both sides stand in apparent agreement over the particular descriptions of the action. They apparently refer to the same action. So, for example, both talk about the 'Incarnation' as if how this event is individuated would pose no specific problems whatsoever. The event is clearly individuated, with the only remaining question being whose intentional action explains it.

However, in failing to problematize the very way in which events/ actions such as the incarnation are individuated and described, the two 
sides in fact end up talking past each other. What I would like to suggest is that the two sides can in fact live with one another if it is understood that each individuates the action and describes it in a different way. Furthermore, when it comes to the economic activity of God, each such activity must be described twice (see Lewis Ayres' (2010: 260-262) use of the concept of redoublement), in order to more adequately bring out its nature.

The philosopher of action (and law) Joel Feinberg has coined a term to express this description relativity of action individuation. He has called it the 'accordion effect'. The principle brings out a peculiar characteristic of the ontology of action. This is the fact that actions are not easily identified and described. There is no single easy way to talk about what $S$ did. Take this classic example:

$S$ is flipping the switch

$S$ is turning on the light

$S$ is illuminating the room

$S$ is preparing to read a book

$S$ is alerting the burglar (of whom he was unaware)

$S$ is startling Mrs. Smith

$S$ is killing Mrs. Smith (due to a heart condition, aggravated by her being startled).

Feinberg suggests that we can contract an action so as to include only its 'proximal' effects (the light coming on, the room being illuminated, etc.), but we can also expand an action to include more 'distal' effects of this action, some of which may be unintended, and some, indeed, taking place at a different time than the time of my flipping of the switch.

'Fine grained' philosophers of action (see, e.g., Goldman 1971) would argue that this list presents us with multiple actions, and not just a single action identified under a variety of descriptions. 'Coarse-grained' theorists, Feinberg being one of them, insist that there is a single action, which one simply identifies, or picks out under a variety of descriptions.

I will pick up this principle of description-relativity in my discussion of how collective actions may be described. The suggestion will be that the same action could be described in a particular way, so as to ascribe it to the agency of an individual, or described in a different way, so as to ascribe it to the agency of a collective. These descriptions are not mutually exclusive precisely because in their redoublement they pick out something about the nature of collective agency. 
The operative distinction I am making is between events, i.e. happenings which take place in the world, and actions, talk of which is a way of correlating events and intentions. Events can be explained as actions of agents.

However, as Feinberg has shown, actions themselves can be described in terms of how they are related to a series of effects. Coarse-grained action philosophers such as Donald Davidson would claim that there are only basic actions such as one's movement of the body. The rest, he says, is up to nature. What he means is that there is always a single action, that of moving one's body. Yet this action is described and identified in relation to the multitude of effects it brings about.

There is a remarkable similarity between this 'coarse' approach and classic Western theism, which holds that God's acts in the economy spring from one eternal will of God. As the late C. J. F. Williams put it: it is 'inaccurate to speak here of acts in the plural, of operationes. The act of creation is one act, a single decree which says 'Fiat' to the entire history of the universe' (Williams 1994: 242). According to the dominant Thomistic strand in this classic Western theism, there is only one act of God, and that is to be himself. However, there are 'created effects' of this single act of will.

As in the case of Feinberg's accordion, descriptions of the one act of God will vary depending on which created effects serve to identify the action. Yet these will nonetheless remain descriptions of the same collective act, which is that of the Trinity as a whole.

This description-relativity of action ascriptions is particularly interesting in the case of collective actions. I will use an example from Christopher Kutz (2000) to illustrate this. Say a friend of mine and I are preparing a picnic together. I intend to use this as an opportunity to relax, whereas my friend intends to use the picnic as an opportunity to discuss a book. While we are both intending to have picnic together, our intentions about what takes place specifically during the picnic may differ. It can thus rightly be said that 'We are jointly preparing a picnic.' However, it would be wrong to say 'We are jointly preparing an opportunity to discuss a book. If we describe the effect of our 'making of sandwiches', 'buying drinks', etc., as a picnic, the action can be ascribed to both of us (it is described as a collective action). However, even though we do end up discussing the book during the picnic, at the time of preparing it only one of us was intending that effect. Thus, my friend's action at the time 
can certainly be described as 'my friend is preparing an opportunity to discuss the book with me'.

It thus appears that the same action can be made out to be an individual, as well as a collective action. Let us call this 'agency toggling. This will become significant in terms of describing trinitarian action as being both collective, as well as individual. The crucial factor is to which (intended or non-intended) effects the action is related.

Let me try to show why this description-relativity of action ascriptions is significant in this context. One recent defender of the 'twin principles', Kyle Claunch, in an otherwise fine article makes the following claim: 'for the historic doctrines of inseparable operations and distinct personal appropriations to be coherent when affirmed together, it must be shown how each specific action appropriated distinctly to one person is simultaneously the unique act of the one person and the common act of the three.' (Claunch 2013: 797) For Claunch, however, this means that any action done by either trinitarian person, must be equally ascribed to the Trinity as a whole. Indeed, he does not hesitate to make the claim that 'the act of assuming human nature [is] peculiar to the Son, common to all three' (Claunch 2013: 797). Claunch says this in the sense that the subject of the incarnation is the Son, while the principle of the Incarnation is the Trinity as a whole.

The difficulty with the principium/terminus approach (or principle/ subject) is (partly) that it removes us from common ways of ascribing actions to subjects, such that we ascribe 'the assumption of human nature' to the whole Trinity, albeit in a way different than it is ascribed to the person of the Son.

My argument, on the contrary, conditions this 'toggling of agency' upon certain redescriptions of the action. The twin principles call for the same action to be ascribed to both the Trinity as a whole, as well as to an individual person. My suggestion is that while it is indeed the same action that is to be thus ascribed, the action is picked out and identified differently.

The action of God in the economy is one and identical with his will. However, as his action unfolds, it brings out a variety of created effects. Now some of these effects are more akin to the distinctive personality of one or the other divine persons and are thus ascribed to it. For example, the revelatory and teaching dimensions of God's action are appropriately related to the Logos, while the sanctifying effects are 
attributed to the Spirit. However, neither of these descriptions of divine action is sufficient. We have covered the ground only once. We now have to redouble these descriptions by ascribing the action to the whole Trinity. But, as I've argued, we will ascribe to the Trinity the same action, yet under a different description. Pace Claunch, the Trinity does not assume human nature. Rather, the Trinity can be said to save, to draw humanity to itself, whereas 'assuming human nature' is only a dimension of salvation and union with God. All the divine persons can be said to save and to draw humanity to Godself. Yet, when that same action of 'redemption' is picked out in terms of one of its effects (assuming human nature), it is only ascribed to the person of the Son.

This asymmetry is a common feature of collective actions. Take for example the collective action, 'The United States declares war on Japan'. Given that such a declaration is accomplished through the signing of an executive order, the following sequence of action descriptions is pretty common sense:

- Roosevelt moves his left arm

- Roosevelt moves the pen on the paper

- R leaves ink marks on the paper

- R signs the document

- R declares war

- The United States declares war on Japan

Or take the example of a soccer match, where the leading team has a one goal advantage. In the final seconds of the match, a defender fouls from the position of last defender, thus preventing the opposing forward from scoring. Per the current rules of the game, the defender is red carded and ejected from the game. As it turns out the resultant penalty shot is wide off the mark and his team goes on to win the game. Consider now how his action might be described:

- Defender X trips forward Y

- X fouls forward $\mathrm{Y}$

- X prevents $Y$ from scoring

- X saves his team

- X eliminates himself from the game

- X's team preserves its lead [insofar as X acts on behalf of the team, his action is ascribed to the team]

- X's team wins the game [while it can be said that the team has been winning the game every second of the play, it is especially true of 
this particular moment of the game, concentrated in the action of this individual player.]

What is peculiar about both of these cases is that while each individual agent (Roosevelt and defender X) acts on behalf of the collective and therefore it can be generally said that the collective acts through them, it is only under certain descriptions that their individual actions can be ascribed to the collective. There is a break-off point in the movement of the accordion, so to speak, where - given the same action description toggling agencies won't work.

So, for example, it makes sense to say that ' $\mathrm{R}$ declares war' and that 'the USA declares war'; but it doesn't make sense to say 'the USA leaves ink marks on the paper', or 'the USA moves its left arm'. Similarly, it will not make sense to say 'X's team eliminates itself out of the game'.

These examples are hopefully sufficient to illustrate the principle that appropriate 'agency toggling' is conditional upon specific action descriptions. They also show how one can equally ascribe one action to an individual agent, as well as to a collective.

\section{TWO TYPES OF COLLECTIVE ACTIONS}

There is one major hurdle, though, that still needs to be cleared. The patristic witness is consistently rejecting 'cooperative' models of relating the three personal agencies. But collective action seems to be precisely cooperative action.

I will argue, though, that not all types of collective action have the form which has worried the Cappadocians and Augustine. To flesh this out we need to turn to a brief phenomenology of collective action.

An essential rule of the ancient grammar is that any action of any triune person needs to be understood as inherently involving the action of all the others. The question, then, is how does the collective action model construe the relationships between component actions? To answer that question I have distinguished between two kinds of collective actions.

The first type of collective action construes the relationship between component actions, and between the component actions and the larger actions in an instrumental and causal way. We may define it thus:

ICA $(x)$ : An action $x$ is a collective action of an instrumental kind if and only if $x$ is a collective action and the individual actions of which it is composed help cause the collective outcome. 
In such actions, the common collective action is 'made up' of its component parts. Examples of such actions abound, from building a house, to playing soccer, winning a war, pushing a piano up the stairs. It is quite clear that the theological usefulness of this type of collective action is very limited. The powers involved are potentially too different to warrant the ascription of different natures. So, for example, both master and serf can collectively work on building the house. Or, to use an Augustinian example, both master and student together sculpt the statue.

We may identify, however, another kind of collective action. Let us call it collective action of a constitutive kind:

CCA $(x)$ : An action $x$ is a collective action of an instrumental kind if and only if $x$ is a collective action and the individual actions of which it is composed are necessarily constitutive of the collective outcome.

Take the example of two friends walking together, dancing together or two lovers kissing. One might say that the individual components of the collective action are analytic to the collective action as such. This is not simply a case of the collective action being completed by these individual acts, but it being constituted as such by these. Our walking together is not a collective action composed out of my walking with you, which makes possible your walking with me. The individual actions are conditions for each other's possibility, one might say, as well as for the possibility of the collective act as a whole. If you stop walking with me, I may not keep on walking with you (although I may keep walking). The action of each agent is embedded and involved in the action of each other agent.

The case of kissing, or of sexual intercourse, of procreation, might be even better examples of CCA, which is probably why the matrimonial metaphors were so popular in explaining the concept of perichoresis.

I am now in a position to cash out the suggestion that triune action in the economy might be understood after the model of collective action, of an appropriate kind. I suggest that we can understand Triune action in the economy on the model of CCA. The Father, Son, and Holy Spirit each act notionally, but these proper actions will only be described in their full ontological totality if they are also described as collective actions (of a constitutive kind) of the whole Trinity. Hence, the outcome of trinitarian action is not composed out of the sum of notional acts. Neither do these notional acts cause each other. Rather, for each trinitarian action in the 
economy, such an action is equally constituted by the notional acts of Father, Son, and Holy Spirit. Hence, the doctrine of appropriation simply enforces the idea that theological descriptions of such actions must aim for their ontological totality, which entails ascribing them to both individual persons, as well as to the whole Trinity.

\section{TRIUNE COLLECTIVE ACTION}

The first point I wish to make is that an understanding of the unity of triune action in terms of a unity of intention is inadequate - if left without further specification. Neither can collective intentionality, as Searle (1990) has shown, be reduced to individual intentionality plus a set of shared beliefs. Searle's solution, to talk about a primitive collective intentionality in the absence of a primitive trans-individual self, is unpersuasive.

Might this be, one wonders, one of these occasions where the doctrine of God supplies precisely the kind of ontology which is needed to make sense of human collective action? Might we say that the cooperation between individual selves dimly mirrors the supreme cooperation between Father, Son, and Holy Spirit? In such a case, it would make theological sense to say that the only truly collective action is God's opera ad extra, since human collective action fails to unify disparate individual selves sufficiently into a pure collective intention. While the demonstration of this point is not my aim here, it does indicate, I believe the fertility of thinking about divine action in terms of collective agency.

Searle's insistence on an exclusively individual intentionality, one might speculate, is precisely a symptom of human failure to appreciate the reality of the trans-individual. It is precisely this myopia that Augustine and Thomas, as well as the Cappadocians were speaking to when they explained the doctrine of appropriation 'on account of our weakness'. This should not be read, as I argued, in the sense that God is intentionally cloaking his true unified agency behind what is only an apparent diversity of individual actions. Rather, these 'diverse' agencies are truly unified, but due to our weakness we are often unable to see the unity. And so we split the operation of the Father from the Son, we distinguish between the God of the Old Testament and the God of Jesus Christ, and so on. It is our minds, trained on distinction and fed on finitude, which fail to see what God has revealed of himself all along. 
Such a perception involves learning to identify the action in a different way, learning to describe it as the action of the whole Trinity. The entailment of this is that we have never adequately described e.g., the Incarnation, as the action of the Son, until we have also described it as the action of the whole Trinity. Each created effect of divine grace must be gone over twice in our efforts to bear witness to its truth.

Merely to talk about the unity of intention between Father, Son, and Holy Spirit is not sufficiently preserving of trinitarian monotheism. Such intentions might still be the individual intentions of persons sharing a composite essence.

What the doctrine of the Trinity supplies is precisely a way of accounting for the Triune we-intentionality in ways which does not reduce it to the I-intentionality of Father, Son, and Holy Spirit, as manifested in their discrete actions. The principle of the opera trinitatis ad extra sunt indivisa is always prefixed by another one: opera trinitatis ad intra sunt divisa. Thus, the Triune intentionality manifested in the economy is identical with the perichoresis of the individual intentionality of the Father, Son, and Spirit, coalescing together in the intra-trinitarian counsel to form this unitary intention.

C. J. F. Williams suggested the analogy of a 'group mind' (Leftow's language). While each divine person has its own will and knowledge, the three wills coalesce in love such that they are entirely open to one another, 'so that each adopts those [knowledge and will] of the other, sees with his eyes, as it were. The barriers that keep us from knowing each other's hearts, save fleetingly [...] are there down eternally.' (Williams (1994: 241)

This makes a further personalist correction to the classic language. The incarnation is appropriate to the Son not simply because of the proper way in which the Son shares in the divine substance (as only begotten of the Father), but also because of his own intention in the divine counsel. The incarnation, then, truly represents the personal identity of the Son, his personal wish and desire.

The crucial difference, though, from reductive models, is that the historical (economic) activity of the Son cannot be fully understood unless it is redoubled, i.e., unless it is described both in terms of an individual intention, as well as in terms of a unified divine intention (constituted by the eternal willing of Father, Son, and Spirit).

We can now think of the opera trinitatis ad extra in terms of an unfolding collective action of God. This action, however, must be 
appropriately understood. It is to be understood on the analogy of a collective action of a constitutive kind (CCA). To speak of a constitutive relation between the actions of the Father, Son, and Spirit best preserves the Cappadocian principle of mutual indwelling, without falling into non-personalist language.

It is still possible to describe an individual component of a CCA as an individual action. 'The dancer is putting his left foot forward'; or, 'she is pressing her lips against his'. But this, by itself, will never account for the full richness of the action, unless a description is given of the action in terms of the collective intentionality involved: 'They are kissing'; 'They are dancing.'

A final word is needed about the principle of appropriation. We are forced to lament appropriation as a mere linguistic device only if we assume that there is only one possible ontology of actions. The action of the Son is not merely appropriated to him, in the sense that the real agent is the Trinity as a whole. But neither is it an individual action which contributes causally to the larger divine collective action. Rather, the action of the Son is mutually constitutive of the actions of the Father and the Spirit, as well as of the action of the three considered as a whole.

Appropriation is indeed a device that is due to our finiteness, for we are not able to entertain these dimensions of description all at once. Moreover, appropriation does not mean that the distinctions we make (between various actions and agencies) are not indicative of a real taxis of the divine action. Rather, it means that whatever these distinctions refer to, it is not of such a nature as to divide his being and action.

I believe this approach preserves the intentions of both unifiers and multipliers. The unity of God's essence is protected by the claim that the divine collective action is not composed of discrete individual actions and intentions, to which it might be reduced. There is a prior triune collective intentionality, which I have localized in the divine 'counsel'. Such an intentionality is not constructed from the created intentionality of, say, the man Jesus - these are effects in time of the one action of God. In that sense, the immanent Trinity grounds the economic Trinity.

On the flip side, such an account preserves the reality and revelatory significance of the individual actions which compose/constitute the one collective action of the Trinity. Non-personalist and modalistic language is avoided in favour of a thinking which prefers personal action to being, or better yet, subordinates being to personal action. 


\section{RESPONDING TO SOME OBJECTIONS}

In the previous pages I have tried to supplement the Social-Trinitarian account of the unity of external operations by (a) appealing to the description relativity of action ascriptions and by (b) extending the unity between token actions beyond mere shared intentions, such that the actions of the Father, Son, and Spirit are understood after the analogy of collective actions of a constitutive kind. There are two stated advantages of this model. First, the unity which characterizes their respective agencies is sufficiently monotheistic. Secondly, specific actions are truly ascribed to individual triune persons, without erasing the fundamental unity of their operation.

Does my approach to inseparable works in terms of CCA sufficiently preserve the distinctness of the persons and their respective actions? Both the social account as well as the Latin approach account for this distinctness in their own ways. Social Trinitarians simply ascribe distinct actions to individual persons, while classically Western trinitarians refer different created effects to the various persons as distinct modes or 'dimensions' of the same action. In tightening the unity of operations I seem to have abandoned both the Latin dimensional approach, which in some cases can be quite concrete, but also a 'distinctive roles' approach characteristic of ST. While I may in this way have avoided the charge of an 'Olympian' approach to the Trinity, it seems as if I have overdetermined the collective action in such a way that each of the persons in themselves can in fact fully account for the collective outcome. As Leftow puts it, 'It could be that the Three overdetermine the divine action, each of them contributing enough of his own to fully account for the divine effect.' (Leftow 2002: 238)

The overdetermination problem does not apply to my account since the individual actions of CCA are not superfluous to the collective outcome, but rather constitutive. This means that each individual action is a condition for the possibility of the other individual actions of the collective members. While together they mutually produce a collective effect, each action taken individually has its own form. Thus, one of the dance partners is pirouetting, while the other is completing another move.

Similarly, the Son's becoming incarnate and the Spirit's indwelling of believers are constitutive of one another as moves within the eternal saving action of God. But this sounds counter-intuitive. How might the 
contemporary action of the Spirit be constitutive of the long-past action of the Son in the incarnation? This is where appropriate description comes in. In fact, the action of the Son in the economy is one and the same with the action of the Spirit. However, because we have identified the action in terms of one of its created effects (incarnation, indwelling), the statement above seems mistaken. If, however, we bear in mind the distinction between the action in itself and the created effects in relation to which we describe the action, the contradiction disappears.

A second objection presents itself at this point. It can be charged that my argument, although moving ST in the direction of a stricter monotheism, still insufficiently safeguards the unity of God. Two people dancing from all eternity are, after all, still two people. The objection could perhaps be stated in Nyssen's language: although Father, Son, and Spirit act in a way that is mutually constitutive, they may still be called in the plural.

In a certain sense, to fully answer this objection would require mounting a fully fledged defence of ST. This is clearly beyond the scope of this paper. Moreover, my argument should not be taken as the expression of a preference for ST. What I set out to do is to explore the ways in which the doctrine of inseparable operations might be defended, should one choose ST.

I do think, however, that an appropriate use of the collective action analogy can strengthen ST's monotheist stance. This model stresses that the discrete actions of the trinitarian persons in the economy should not be taken as a dogmatically certain instance of revelation, without qualification. Such a qualification is provided by the axiom that every action of each person is constituted by the actions of the other two. Together these actions are caught up in an eternal unity of pure act. Barth is exactly right to write that if we confused the analogy with the thing itself, if we equated the distinctions that are comprehensible to us with those that are not, in other words, if we thought we had comprehended the essence of God in comprehending his work, we should be plunged at once into the error of tritheism' (Barth 1975: 373).

I am not convinced, though, that merely appealing to the mutualconstitution of the economic acts is sufficient to establish monotheism. As I have already indicated, the particular distribution of agencies within the economic collective act is reflective of the eternal taxis of the inter-personal relationships themselves. It is primarily at this level that a defence of monotheism has to be mounted. 


\section{BIBLIOGRAPHY}

Aquinas, Thomas. 1981. The Summa Theologica of St. Thomas Aquinas, trans. by Fathers of the English Dominican Province (Westminster, MD: Christian Classics)

Atwell, John E. 1969. 'The Accordion Effect Thesis', The Philosophical Quarterly, 19 (77): 337-342

Ayres, Lewis. 2010. Augustine and the Trinity (Cambridge: Cambridge University Press)

Barnes, Michel R. 2001. The Power of God: In Gregory of Nyssa's Trinitarian Theology (Washington, D.C.: Catholic University of America Press)

Barth, Karl. 1975. Church Dogmatics, trans. by G. W. Bromiley \& Thomas Forsyth Torrance (Edinburgh: T\&T Clark)

Basil the Great. 1999. The Holy Spirit, in Nicene and Post-Nicene Fathers, 2nd series, vol. 8, ed. by Phillip Schaff \& Henry Wace (Peabody, MA: Hendrickson) Claunch, Kyle. 2013. 'What God Hath Done Together: Defending the Historic Doctrine of the Inseparable Operations of the Trinity', Journal of the Evangelical Theological Society, 56 (4): 781-800

Cohen, Philip R., Jerry L. Morgan \& Martha E. Pollack (eds). 1990. Intentions in Communication (Cambridge, Mass.: MIT)

Davidson, Donald. 2001. Essays on Actions and Events (Oxford: Clarendon Press)

Davis, Stephen T., Daniel Kendall \& Gerald O'Collins (eds.). 2002. The Trinity: An Interdisciplinary Symposium on the Trinity (Oxford: Oxford University Press)

Duffy, Stephen J. 2005. 'Experience of Grace', in Declan Marmion \& Mary E. Hines (eds), The Cambridge Companion to Karl Rahner (Cambridge: Cambridge University Press), pp. 43-62

Gregory of Nyssa. 2007. Gregory of Nyssa, Dogmatic Treatises, vol. 5: Nicene and Post-Nicene Fathers, ed. by Philip Schaff \& Henry Wace (New York, NY: Cosimo Classics)

Goldmann, Alvin. 1971. 'The Individuation of Action', Journal of Philosophy, 68 (21): 761-774

Heppe, Heinrich. 2007. Reformed Dogmatics, trans. by G. T. Thompson (Eugene, OR: Wipf and Stock)

Holmes, Stephen R. 2012. The Quest for the Trinity: The Doctrine of God in Scripture, History, and Modernity (Downers Grove, IL: IVP Academic)

Holmes, Stephen R. 2001. "Something Much Too Plain to Say": Towards a Defence of the Doctrine of Divine Simplicity', Neue Zeitschrift für Systematische Theologie und Religionsphilosophie, 43 (1): 137-154

Kutz, Christopher. 2001. 'Acting Together', Philosophy and Phenomenological Research, 61 (1): 1-31 
LaCugna, Catherine Mowry. 1991. God for Us: The Trinity and Christian Life (San Francisco: HarperSanFrancisco)

Leftow, Brian. 2002. 'Anti-Social Trinitarianism', in Stephen T. Davis, Daniel Kendall \& Gerald O'Collins (eds.), The Trinity: An Interdisciplinary Symposium on the Trinity (Oxford: Oxford University Press), pp. 203-248

Marmion, Declan, \& Mary E. Hines (eds). 2005. The Cambridge Companion to Karl Rahner (Cambridge: Cambridge University Press)

Muller, Richard A. 2001. Post-Reformation Reformed Dogmatics: The Rise and Development of Reformed Orthodoxy, Ca. 1520 to Ca. 1725, vol. 4 (Grand Rapids, MI: Baker Academic)

Padgett, Alan (ed.). 1994. Reason and the Christian Religion (Oxford: Clarendon) Peters, Ted. 1993. God as Trinity: Relationality and Temporality in Divine Life (Louisville, KY: Westminster/J. Knox Press)

Rahner, Karl. 1970. The Trinity, trans. by Joseph Donceel (Tunbridge Wells: Burns \& Oates)

Schwöbel, Christoph. 1992. God: Action and Revelation (Kampen: Kok Pharos Pub. House)

Searle, John L. 1990. 'Collective Intentions and Actions', in Philip R. Cohen, Jerry L. Morgan \& Martha E. Pollack (eds), Intentions in Communication (Cambridge, Mass.: MIT), pp. 401-415

Searle, John L. 1996. The Construction of Social Reality (New York: Penguin)

Stramara, Daniel F., Jr. 1998. 'Gregory of Nyssa’s Terminology for Trinitarian Perichoresis', Vigiliae Christianae, 52 (3): 257-263

Stump, Eleonore. 1986. 'Dante's Hell, Aquinas's Moral Theory, and the Love of God', Canadian Journal of Philosophy, 16 (2): 181-198

Stump, Eleonore, \& Norman Kretzmann. 1981. 'Eternity', The Journal of Philosophy, 78 (8): 429-458

Stump, Eleonore, \& Norman Kretzmann. 1985. 'Absolute Simplicity', Faith and Philosophy, 2 (4): 353-382

Swinburne, Richard \& Alan G. Padgett. 1994. Reason and the Christian Religion: Essays in Honour of Richard Swinburne (Oxford: Clarendon Press)

Vanhoozer, Kevin J. 2010. Remythologizing Theology Divine Action, Passion, and Authorship (Cambridge, UK: Cambridge University Press)

Velleman, J. David. 1997. 'How To Share An Intention', Philosophy and Phenomenological Research, 57 (1): 29-50

White, Alan R. (ed.). 1968. The Philosophy of Action (London: Oxford University Press)

Williams, C. J. F. 1994. 'Neither Confounding the Persons nor Dividing the Substance', in Alan Padgett (ed.), Reason and the Christian Religion (Oxford: Clarendon), pp. 227-243 